\title{
TURBIDITY PATTERNS IN THE ALBUFERA LAKE, SPAIN, AND THEIR RELATION TO IRRIGATION CYCLES
}

\author{
MARÍA-TERESA SEBASTIÁ-FRASQUET ${ }^{1}$, JESÚS A. AGUILAR-MALDONADO², \\ EDUARDO SANTAMARÍA-DEL-ÁNGEL ${ }^{2} \&$ VICENT ALTUR-GRAU ${ }^{1}$ \\ ${ }^{1}$ Institut d'Investigació per a la Gestió Integrada de Zones Costaneres, Universitat Politècnica de València, Spain \\ ${ }^{2}$ Facultad de Ciencias Marinas, Universidad Autónoma de Baja California, Mexico
}

\begin{abstract}
The Albufera Natural Park (Valencia, Spain) is one of the most representative coastal wetlands in the Mediterranean basin. It holds several protection designations at national and international level, such as Spanish Natural Park, Special Protection Areas (SPAs) for birds, Sites of Community Importance (SCIs) and Ramsar Site. Both the park and its main lake, Albufera's lake, face several environmental problems. One of them is reduced transparency and lake clogging. The lake is highly dependent on the rice cycle and on irrigation returns, mainly from the Acequia Real. In this study, we analyse the monthly transparency and turbidity patterns during year 2018, and we relate them to irrigation cycles. We used Sentinel 2A satellite images from the European Space Agency, which have an atmospheric correction. Remote sensing results were compared with in situ data from the monitoring program of the Environment General Subdivision of the regional government. This monitoring program samples five points on a monthly basis, and analyses Secchi disk depth, suspended solids and chlorophyll a. Our results show the temporal and spatial pattern of turbidity in the Albufera lake which offers relevant information for water resources management.
\end{abstract}

Keywords: sentinel, satellite, turbidity, Secchi disk.

\section{INTRODUCTION}

Wetlands are of vital importance because they provide a great variety of ecosystem services [1]. Among others, they are an important freshwater reserve and a source for groundwater recharge, and in coastal areas they provide defence against marine intrusion. However, they are among the most endangered ecosystems, especially in coastal areas due to several anthropogenic threats, e.g. treated or untreated wastewater discharges or reduced water inputs due to agricultural uptake. These threats cause changes in water quality parameters such as reduced transparency and increased phytoplankton biomass [2]. In recent years there is a growing interest in developing indicators to monitor environmental change in these areas [3]. Many scientific studies have addressed the issue of mapping and monitoring natural habitats through remote sensing and obtaining indicators of their conservation status [3].

Remote sensing is a valuable tool for monitoring several parameters. Some studies have analysed the distribution of sediment in suspension allowing the construction of a synoptic description of turbidity patterns [4]. MODIS images have been used to determine the spatio-temporal variability of turbidity from their reflectance; this variability has been related to the Secchi disk depth in ocean and coastal waters [5]-[8] and to a lesser extent in rivers [9]. Also, Landsat reflectance images have been used (in a turbid estuary [10]), and their signal penetration at different depths [11], [12]. Studies on wetland water bodies are more scarce due to a higher complexity caused by their typical shallowness and turbidity.

The determination of turbidity in shallow waters requires the use of spectral bands that are sensitive to turbidity and have a limited depth penetration to avoid substantial interference from the bottom [13]. Water absorption increases rapidly from red $(645-700 \mathrm{~nm})$ to red edge NIR (700-780 nm) [14]. This absorption limits the light received from the bottom, while it returns light scattered by suspended materials. This offers a good balance between turbidity 
detection and bottom detection [15]. Several studies have already indicated that these spectral bands are appropriate for the monitoring of turbidity or suspended solids in optically complex regions [13], [15], [16]. According to [13], the $704 \mathrm{~nm}$ wavelength gives the greatest return of light to the sensor at depths between one and two meters. However, at longer wavelengths, sensitivity to suspended material in shallow and highly turbid waters is lost [13].

In addition to remote sensors, a simple and low-cost way of observing changes in suspended matter is the Secchi disk depth. It is a measure of water transparency, measured by lowering a white (in marine waters) or black-and-white (in continental waters) disk with a diameter of about $30 \mathrm{~cm}$ in the water until it is no longer visible to an observer on the surface [8], [17].

The objective of this research was to analyse the monthly transparency and turbidity pattern during year 2018 in the Albufera lake, a shallow and turbid lake from the wetland Albufera Natural Park (Valencia, Spain). This objective was achieved using Sentinel 2A images and in situ data from the monitoring program of the Environment General Subdivision of the regional government.

\section{MATERIALS AND METHODS}

\subsection{Study area}

The Albufera Natural Park is one of the most representative coastal wetlands in the Mediterranean basin. It is a shallow and hypertrophic coastal lagoon and is located on the Mediterranean coast, $10 \mathrm{~km}$ south of the city of Valencia (Fig. 1) [18], [19].

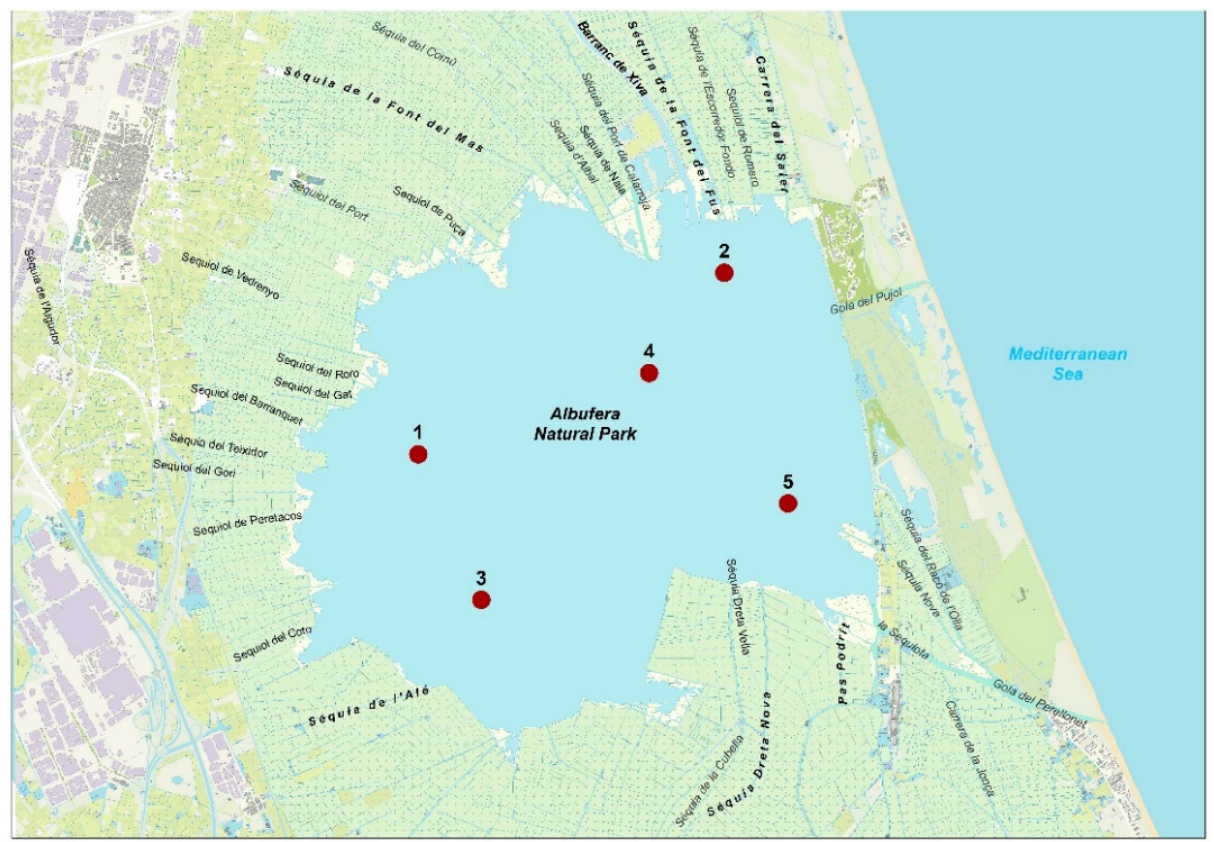

Figure 1: Study area, the Albufera lake and surroundings. Numbered red points are sampling stations from the monitoring program of the Environment General Subdivision of the Valencian government. 
It holds several protection designations at national and international level, such as Spanish Natural Park, Special Protection Areas (SPAs) for birds, Sites of Community Importance (SCIs) and Ramsar Site. However, the park faces several environmental problems. This research focus on its main lake, Albufera's lake. The lake is highly dependent on the rice cycle, which is the main crop in the watershed, and on irrigation returns, mainly from the Acequia Real. The lake is connected to the Mediterranean Sea through three floodgates, "Golas" in Spanish, from North to South, Gola de Pujol, Gola del Perelló and Gola del Perellonet. These floodgates are operated to satisfy rice crop needs. The floodgates are open from January to March to allow the water level of the lake to increase mainly during this period for irrigation. During the rice growing season (April-September) the floodgates remain closed to allow fields flooding and with an insignificant flow to the lake. The doors open in September to allow the rice fields drying for the rice harvest. Finally, the doors are closed again in November to allow the flooding of the harvested rice fields, which favours the mineralization of nutrients [20]. It also receives some treated wastewater from nearby urban and industrial areas [21]. The lake exhibits reduced transparency and it is threatened with clogging, hence the importance of studying turbidity patterns.

\subsection{Secchi disk and suspended matter}

Secchi disk depth $(\mathrm{cm})$ and suspended matter $(\mathrm{mg} / \mathrm{L})$ were measured monthly by the monitoring program of the Environment General Subdivision of the Valencian government in the five red points depicted in Fig. 1 from 1995 to 2018. These data can be accessed at the website www.agroambient.gva.es/es/web/espacios-naturales-protegidos/programa-deseguimiento-de-zonas-humedas.

Secchi disk depth was measured with a $30 \mathrm{~cm}$ diameter black-and-white disk, which was submerged in the water until it was no longer visible to an observer on the surface [8], [17]. Secchi disk depth is inversely proportional to the amount of dissolved and/or particulate matter present in the water column; thus, is a turbidity indicator. Suspended matter (total suspended solids, TSS) was determined following the Standard Methods (2005) procedure, 2540D, for surface waters. Secchi disk depth and suspended matter data were standardized using the following equation:

$$
Z=\frac{x_{i}-\bar{x}}{S D}
$$

where $x_{i}$ is the month datum of year $i, \bar{x}$ is the month average from 1995 to 2018 , and $S D$ is the monthly standard deviation from 1995 to 2018.

The standardized values were classified as follows: (1) values in the interval $(-1,1)$ indicate average values; $(2)$ values in the interval $(1,2)$ are above average conditions, and (3) values $(>2)$ are highly anomalous. The limit of the anomalous conditions was based on an Inverse Cumulative Distribution Function (ICDF), in a normal distribution, which defines 2 standard deviations as the limit of values without noise with $90 \%$ confidence [22].

Then, the month average of the standardized values from 1995 to 2018 was calculated to characterize each month.

\subsection{Satellite data}

Sentinel 2A and 2B images were obtained from the Sentinel Scientific Data Hub (https://scihub.copernicus.eu/). For each month the better image available was selected, that is, the image with less cloud coverage. Images were processed at Level-2A, that is, an 
orthoimage Bottom-Of-Atmosphere (BOA) corrected the reflectance product. The band 5 $(705 \mathrm{~nm})$ used in this work has a spatial resolution of 20 meters (ESA).

The reflectance values of band $5(705 \mathrm{~nm})$ were spatially standardized following eqn (1). Spatial standardization means that we analyse the spatial distribution of reflectance values. So, in this case eqn (1) variables are the following: $x_{i}$ is the month datum of sampling station $i$ pixel, $\bar{x}$ is the month average of all Albufera lake pixels, and $S D$ is the monthly standard deviation of all Albufera lake pixels.

\section{RESULTS AND DISCUSSION}

Suspended matter concentration shows a temporal pattern in the Albufera lake. Suspended matter is higher from March to October in all sampling stations (except sampling station 1 from March to August), and thus the Secchi disk depth is lower in March-October (Fig. 2).

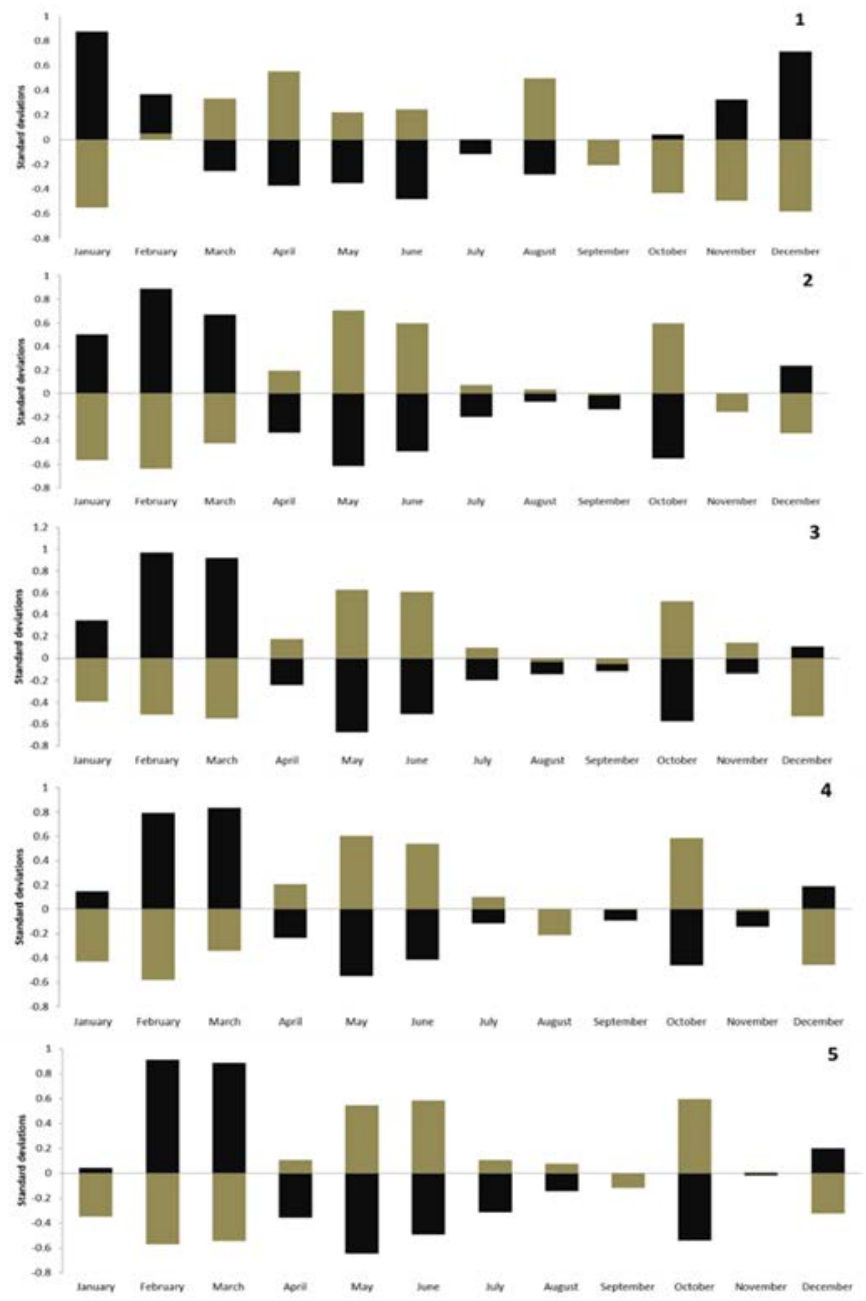

Figure 2: Standardized monthly averages of Secchi disk depth (black bars) and suspended matter (green bars) for the period from 1995 to 2018, in the five sampling stations of Albufera lake. 
During the study period from 1995 to 2018, the lowest water transparency is in May-June and October in sampling stations 2 to 5. Sampling station 1 exhibits a little different behaviour, that is, lower water transparency is maintained from March to September, and transparency only shows a recovery during November to January.

To better analyse the spatial pattern, the monthly standardized reflectances, band 5 $(705 \mathrm{~nm}$ ) from Sentinel 2A, for year 2018 can be examined in Fig. 3. This reflectance represents turbidity as follows: values in the interval $(-1,1)$ indicate average values (blue colour); values in the interval $(1,2)$ are above average conditions (yellow colour), and values $(>2)$ are highly anomalous (red colour).

The spatial distribution of turbidity observed in Fig. 3 is related to meteorological events. From October to December 2018, several heavy rain events carried more sediments to the lake through surface runoff. Rain events were linked to turbidity values above the average
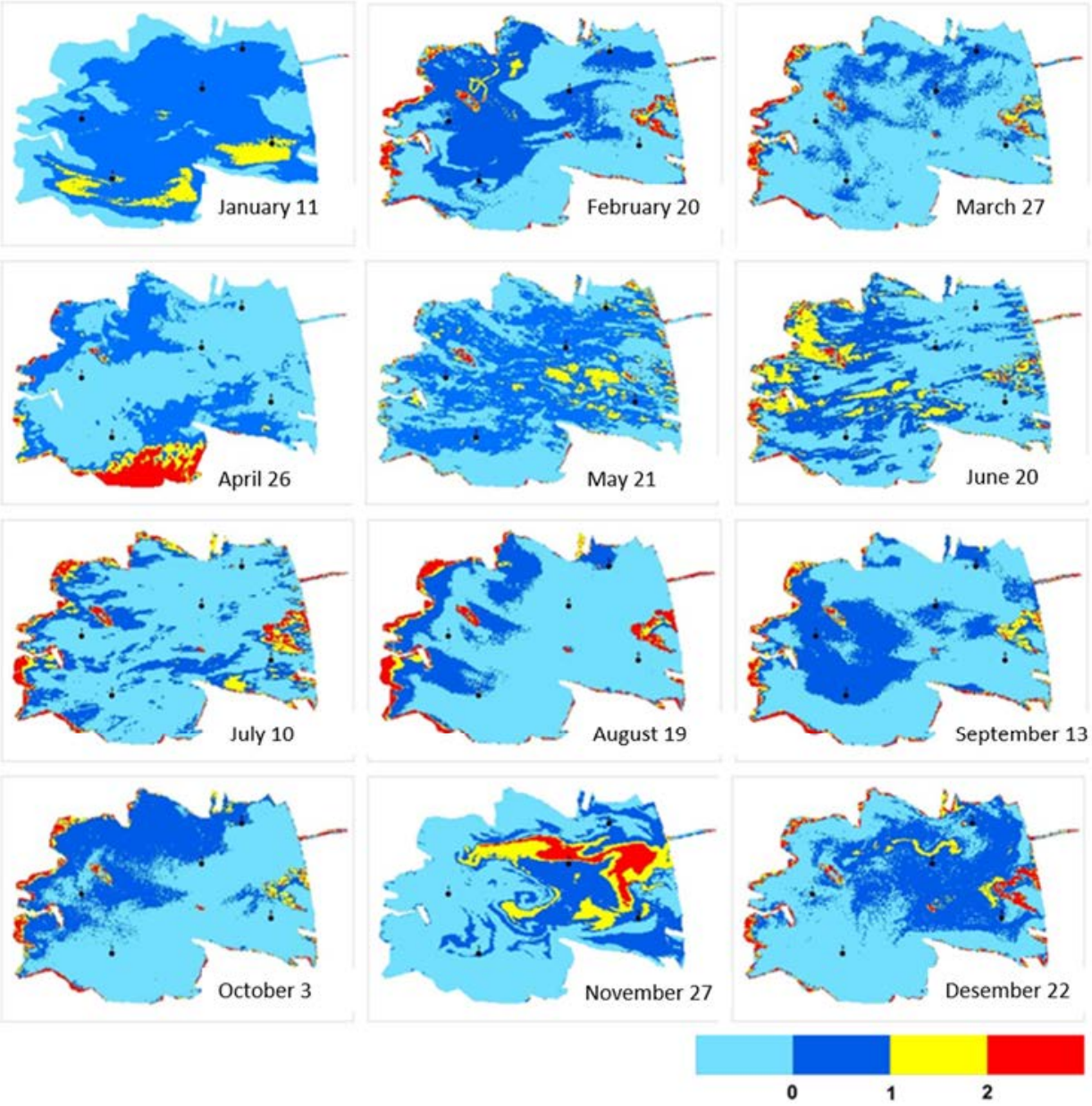

Figure 3: Monthly standardized reflectances band $5(705 \mathrm{~nm})$ from Sentinel 2A, year 2018, in the Albufera lake. Turbidity is represented as follows: values in the interval $(-1,1)$ indicate average values; values in the interval $(1,2)$ are above average conditions, and values $(>2)$ are highly anomalous. 
ones (yellow colour) and even highly anomalous ones (red colour). During this period the floodgates were opened and allowed a discharge to the sea through the "Golas". From July to September, during the rice growing season, when freshwater inputs to the lake are much more reduced, the most important variable is east wind. The wind dominant direction from sea to land causes the accumulation of suspended material in the west area of the lake. In April a false anomaly is observed, which was due to cloud presence. The study images were selected taking into account the lowest cloud coverage to avoid these interferences, but no better image was available in April 2018.

A statistical analysis was done to check the correlation between remote sensing and in situ information. The monthly standardized data of Secchi disk was correlated with standardized reflectance of Sentinel band 5 (Table 1). According to p-value, the correlation was statistically significant ( $p$-value $<0.05$ ) for all sampling stations except sampling station 1 .

Table 1: Correlation between the monthly standardized data of Secchi disk and band 5 $(705 \mathrm{~nm})$ of Sentinel 2.

\begin{tabular}{|l|c|c|}
\hline Sampling stations & Pearson correlation & P-value \\
\hline 1 & 0.574 & 0.051 \\
\hline 2 & 0.579 & 0.048 \\
\hline 3 & 0.592 & 0.042 \\
\hline 4 & 0.623 & 0.031 \\
\hline 5 & 0.637 & 0.026 \\
\hline
\end{tabular}

According to the morphometric analysis carried out in 2005, the average depth of the Albufera lake was $0.9 \mathrm{~m}$ [23]. The results of the statistical analysis corroborate that the reflectance of band $5(705 \mathrm{~nm})$ is suitable for the analysis of shallow lakes, such as the Albufera lake, even in eutrophic conditions. Sampling station 1 showed a temporal and spatial behaviour that differed from the others. This station is located at the shallower area of the Albufera lake $(<0.9 \mathrm{~m})$.

The analysis of turbidity gives information about organic and inorganic suspended materials, that is, about phytoplankton and inorganic particles. Previous remote sensing research [24], [25] focuses mainly on chlorophyll $a$ study, which is an indicator of phytoplankton biomass. Our study of turbidity patterns provides an important supplementary information to those previous studies. Soria [23] demonstrated that flushing pulses are key to improve water quality and to remediate eutrophication. In our study, we demonstrated that during important rain events, the turbidity pattern shows higher values towards the floodgates "Golas". Then, it is important that during rain events the connection between the lake and the sea remains open to allow sediment discharge and avoid lake clogging. Increasing flushing pulses frequency would be a good management measure that could help in alleviating not only eutrophication problems but also lake clogging.

\section{CONCLUSION}

Turbidity dynamics in the Albufera lake are variable along the year. The main variables affecting turbidity patterns are precipitation, wind and management of floodgates. Having taken into account the temporal and spatial pattern of suspended matter, it is important to develop a conscious management of irrigation practices. Closing the floodgates during important rain events prevents the discharge of solids to the sea. This can have several 
negative effects both for the lake and for the receiving coastal waters and ecosystem. The lake has a clogging trend that can be worsened due to the accumulation of non-discharged solids. The beaches next to the receiving coastal waters do not receive an important load of solids to nourish them.

\section{ACKNOWLEDGEMENTS}

María-Teresa Sebastiá-Frasquet was beneficiary of the CAS18/00107 post-doctoral research grant, supported by the Spanish Ministry of Education Culture and Sports during her stay at the Universidad Autónoma de Baja California (Mexico), image processing was partially developed during the stay. The authors want to thank María Sahuquillo, from the Environment General Subdivision of the Valencian government, and Paloma Mateache, Natural Park director for their insightful knowledge of the lake dynamics and help in interpreting the results.

\section{REFERENCES}

[1] Sebastiá-Frasquet, M.-T., Altur, V. \& Sanchis, J.-A., Wetland planning: Current problems and environmental management proposals at supra-municipal scale (Spanish Mediterranean Coast). Water, 6, pp. 620-641, 2014.

[2] Sebastiá, M.-T., Rodilla, M., Sanchis, J.-A., Altur, V., Gadea, I. \& Falco, S., Influence of nutrient inputs from a wetland dominated by agriculture on the phytoplankton community in a shallow harbour at the Spanish Mediterranean coast. Agriculture, Ecosystems \& Environment, 152, pp. 10-20, 2012.

[3] Tiner, R.W., Remotely-sensed indicators for monitoring the general condition of "natural habitat" in watersheds: An application for Delaware's Nanticoke River watershed. Ecological Indicators, 4(4), pp. 227-243, 2004.

[4] Nechad, B., Ruddick, K. \& Park, Y., Calibration and validation of a generic multisensor algorithm for mapping of total suspended matter in turbid waters. Remote Sensing of Environment, 114(4), pp. 854-866, 2010.

[5] Aguilar-Maldonado, J.A., Santamaría-del-Ángel, E. \& Sebastiá-Frasquet, M.T., Reflectances of SPOT multispectral images associated with the turbidity of the Upper Gulf of California. Revista de Teledetección, 50, pp. 1-16, 2017.

[6] Chust, G., Sagarminaga, Y., Borja, A. \& Valencia, V., Extracción de propiedades ópticas en aguas costeras del Golfo de Vizcaya mediante MODIS-250 m. Revista de Teledetección, 25, pp. 124-128, 2006.

[7] Wang, M. \& Shi, W., Estimation of ocean contribution at the MODIS near-infrared wavelengths along the east coast of the U.S.: Two case studies. Geophysical Research Letters, 32(13), 2005.

[8] Wang, S., Lee, Z., Shang, S., Li, J., Zhang, B. \& Lin, G., Deriving inherent optical properties from classical water color measurements: Forel-Ule index and Secchi disk depth. Optics Express, 27(5), pp. 7642-7655, 2019.

[9] Dogliotti, A., Ruddick, K., Nechad, B. \& Lasta, C., Improving water reflectance retrieval from MODIS imagery in the highly turbid waters of La Plata river. Presented at Proceedings of VI International Conference. Current Problems in Optics of Natural Waters, St. Petersburg, Russia, 2011.

[10] Doxaran, D., Castaing, P. \& Lavender, S., Monitoring the maximum turbidity zone and detecting fine-scale turbidity features in the Gironde estuary using high spatial resolution satellite sensor (SPOT HRV, Landsat ETM+) data. International Journal of Remote Sensing, 27(11), pp. 2303-2321, 2006. 
[11] Baeye, M., Quinn, R., Deleu, S. \& Fettweis, M., Detection of shipwrecks in ocean colour satellite imagery. Journal of Archaeological Science, 66, pp. 1-6, 2016.

[12] Lee, Z., Shang, S., Qi, L., Yan, J. \& Lin, G., A semi-analytical scheme to estimate Secchi-disk depth from Landsat-8 measurements. Remote Sensing of Environment, 177, pp. 101-106, 2016.

[13] Caballero, I., Stumpf, R.P. \& Meredith, A., Preliminary assessment of turbidity and chlorophyll impact on bathymetry derived from sentinel-2A and sentinel-3A satellites in South Florida. Remote Sensing, 11(6), p. 645, 2019.

[14] Vanhellemont, Q. \& Ruddick, K., Acolite for Sentinel-2: Aquatic applications of MSI imagery. Proceedings of the 2016 ESA Living Planet Symposium, pp. 9-13, 2016.

[15] IOCCG, Remote sensing of ocean colour in coastal, and other optically-complex waters. Reports of the International Ocean-Colour Coordinating Group, ed. S. Sathyendranath, No. 3, 2000.

[16] Toming, K., Kutser, T., Laas, A., Sepp, M., Paavel, B. \& Nõges, T., First experiences in mapping lake water quality parameters with Sentinel-2 MSI imagery. Remote Sensing, 8(8), p. 640, 2016.

[17] Wernand, M.R., On the history of the Secchi disc. Journal of the European Optical Society-Rapid Publications, 5, 2010.

[18] Soria, J.M., Miracle, M.R. \& Vicente, E., Aporte de nutrientes y eutrofización de la Albufera de Valencia. Limnetica, 3(2), pp. 227-242, 1987.

[19] Soria, X. et al., Validación de algoritmos para la estimación de la clorofila-a con Sentinel-2 en la Albufera de València. Proceedings of the XVII Congreso de la Asociación Española de Teledetección, pp. 289-292, 2017.

[20] Romo, S., García-Murcia, A., Villena, M.J., Sanchez, V. \& Ballester, A., Phytoplankton trends in the lake of Albufera de Valencia and implications for its ecology, management, and recovery. Limnetica, 27, pp. 11-28, 2008.

[21] Doña, C. et al., Integrated satellite data fusion and mining for monitoring lake water quality status of the Albufera de Valencia in Spain. Journal of Environmental Management, 151, pp. 416-426, 2015.

[22] Santamaría-del-Ángel, E., Sebastia-Frasquet, M.T., Gonzalez-Silvera, A., AguilarMaldonado, J, Mercado-Santana, A. \& Herrera-Carmona, J., Uso Potencial de las Anomalías Estandarizadas en la Interpretación de Fenómenos Oceanográficos Globales a Escalas Locales. Costas y Mares Mexicanos: Construyendo la Línea Base para su Futuro Sostenible, Oceanografía Fisicoquímica, eds E. Rivera-Arriaga, P. Sánchéz-Gil \& J. Gutiérrez, J. México, EPOMEX: Universidad Autónoma de Colima, 2019.

[23] Soria, J.M., Past, present and future of la Albufera of Valencia Natural Park. Limnetica, 25(1-2), pp. 135-142, 2006.

[24] Sòria-Perpinyà, X. et al., Remote sensing application for the study of rapid flushing to remediate eutrophication in shallow lagoons (Albufera of Valencia). Hydrobiologia, 829, pp. 125-132, 2019.

[25] Sòria-Perpinyà, X. et al., Monitoring the ecological state of a hypertrophic lake (Albufera of València, Spain) using multitemporal Sentinel-2 images. Limnetica, 38(1), pp. 457-469, 2019. 